\title{
Aktivitas Antibakteri dan Uji Sifat Fisik Sediaan Gel Dekokta Sirih Hijau (Piper betle L.) Sebagai Alternatif Pengobatan Mastitis Sapi
}

\author{
Antibacterial Activity and Physical Evaluation of Piper betle L. Decoction Gel as an Alternative \\ Treatment for Mastitis
}

\author{
Iramie Duma Kencana Irianto ${ }^{1^{*}}$, Purwanto ${ }^{2}$, Marwan Triafrian Mardan $^{3}$ \\ 1 Prodi DIII Farmasi, Poltekkes Bhakti Setya Indonesia, Yogyakarta \\ 2 Departemen Biologi Farmasi, Fakultas Farmasi, Universitas Gadjah Mada, Yogyakarta \\ ${ }^{3}$ Mahasiswa sarjana, Fakultas Farmasi, Universitas Gadjah Mada, Yogyakarta \\ Corresponding author: Iramie Duma Kencana Irianto: Email: iramie.d.k.i@poltekkes-bsi.ac.id \\ Submitted: 10-03-2020 Revised: 19-03-2020 Accepted: 11-05-2020
}

\begin{abstract}
ABSTRAK
Maastitis adalah radang yang terjadi pada ambing susu sapi dan dapat menyebabkan penurunan produktivitas sapi perah secara drastis. Senyawa fenolik alam seperti flavonoid dan tanin diketahui dapat membunuh bakteri $S$. aureus dan E. coli. Dekokta daun sirih hijau (DDSH) yang mengandung senyawa fenolik pada konsentrasi $20 \%$ diketahui mampu membunuh bakteri S.aureus dan E.coli. Sediaan gel adalah sediaan yang bersifat menyejukkan, melembabkan, mudah penggunaannya. Penelitian ini bertujuan untuk mencari formula terbaik dengan memperhatikan daya antibakteri dan sifat fisik gel dalam setiap formula. Hasil penelitian ini menunjukkan bahwa peningkatan konsentrasi DDSH menghasilkan gel dengan $\mathrm{pH}$ dan viskositas yang semakin rendah, namun daya antibakteri yang semakin besar, sedangkan peningkatan konsentrasi karbopol menyebabkan peningkatan viskositas gel. Berdasarkan daya antibakteri dan sifat fisik gel dalam setiap formula, maka formula 4 (terdiri dari 62,5\% DDSH dan 0,875\% karbopol) merupakan formula yang optimal dalam penelitian ini.
\end{abstract}

Kata kunci: gel; dekokta; sirih hijau; anti bakteri

\begin{abstract}
Mastitis is inflammation in mammae tissue of pet including cow and able to cause a drastic decrease in cow productivity. Natural phenolic compound such flavonoid and tannin has been known as antibacterial against S.aureus and E.coli. Piper betle decoction (PBD) which contains phenolic compounds at the concentration of $20 \%$ was reported able to eradicate S.aureus and E.coli. Gel is pharmaceutical dosage form that are soothing, moisturizing, and easy to use. This study aimed to find the best formula which concerned to the antibacterial activity and physical properties of the gel in each formula. This result showed that increasing of PBD concentration resulted a gels with lower $p H$ and viscosity, but greater antibacterial activity while increasing of carbopol concentration causes an increase in gel viscosity. Based on the antibacterial activity and physical properties of the gel in each formula, formula 4 (consists of 62,5\% PBD and 0,875\% carbopol) is the optimal formula in this study.
\end{abstract}

Keywords: gel; decoction; Piper betle; antibacterial

\section{PENDAHULUAN}

Indonesia merupakan negara dengan kekayaan alam yang melimpah, baik dari sektor peternakan dan obat tradisional. Pada sektor peternakan, sapi perah merupakan jenis sapi yang menghasilkan susu dalam jumlah besar dan termasuk salah satu ternak unggulan Indonesia (Surjowardojo, 2011). Pada sektor obat tradisional, Indonesia memanfaatkan bahan nabati, hewani, galenik yang telah digunakan secara turun temurun untuk mengobati penyakit, seperti daun sirih hijau yang merupakan tanaman asli Indonesia (DepKes RI, 2012).

Pada pemeliharaan sapi perah sering ditemukan permasalahan kesehatan, diantaranya penyakit mastitis, yaitu suatu reaksi di dalam ambing yang timbul akibat infeksi oleh bakteri, zat kimia, luka bakar atau luka mekanis, yang ditandai dengan peradangan. Selain perubahan patologi dalam jaringan tersebut, mastitis ini dapat menyebabkan perubahan fisik, kimia dan bakteriologi dalam susu yang dihasilkan 
Tabel I. Formula gel dekokta daun sirih hijau

\begin{tabular}{lccccc}
\hline \multirow{2}{*}{ Bahan } & \multicolumn{5}{c}{ Konsentrasi (\%) } \\
\cline { 2 - 6 } & F1 & F2 & F3 & F4 & F5 \\
\hline Dekokta daun sirih & 10 & 27,5 & 45 & 62,5 & 80 \\
Karbopol & 2 & 1,625 & 1,25 & 0,875 & 0,5 \\
NaOH & 0,8 & 0,65 & 0,5 & 0,35 & 0,2 \\
Metil paraben & 15 & 15 & 15 & 15 & 15 \\
Glliserin & 0,2 & 0,2 & 0,2 & 0,2 & 0,2 \\
Akuades & Ad 100 & Ad 100 & Ad 100 & Ad 100 & Ad 100 \\
\hline
\end{tabular}

(Verbree dkk., 2017). Hasil penelitian membuktikan bahwa penurunan produksi susu akibat mastitis dapat mencapai $70 \%$ dan menyebabkan peningkatan kematian sapi per tahun. Hal ini tentu dapat berdampak buruk pada biaya perawatan dan pengobatan sapi perah (Agustinus, 2015; Marsono dkk., 2017). Penyebab utama mastitis adalah bakteri Gram positif genus Staphylococcus sp. dan Streptococcus sp. serta bakteri Gram negatif seperti Escherichia coli. Bakteri tersebut menyerang secara lokal maupun sistemik pada kelenjar susu sapi perah saat fase nifas hingga awal menyusui (Cazoto dkk., 2011; Nurhayati dan Martindah, 2015), dan dapat berpindah melalui tangan pemerah atau peralatan pembersih puting susu.

Penggunaan antibiotik seperti penisilin, neomisin, amoksisilin dan streptomisin biasa digunakan untuk mengobati mastitis. Namun penggunaan antibiotik ini tidak selalu berhasil karena dapat menimbulkan resistensi antibakteri (Schmelcher dkk., 2012). Obat tradisional seperti daun sirih mengandung berbagai macam senyawa aktif yang bersifat komplementer. Menurut Marsono dkk. (2017), dekokta daun sirih hijau yang dengan konsentrasi 20\% mampu membunuh bakteri S.aureus dan E. coli karena mengandung flavonoid, tanin dan saponin. Proses ekstraksi daun sirih dengan metode dekokta dapat mengoptimalkan proses ekstraksi karena proses penyarian dilakukan dalam waktu yang lebih lama $\left(90^{\circ} \mathrm{C}\right.$ selama 30 menit) sehingga kandungan senyawa aktif dapat tersari lebih banyak. Untuk memudahkan aplikasi obat secara topikal, dibutuhkan bentuk sediaan yang sesuai, yang salah satunya adalah gel. Sediaan ini mempunyai sifat menyejukkan, melembabkan, dan mudah penggunaannya (Nikam, 2017). Dari dasar pengetahuan ini maka peneliti tertarik untuk memformulasikan dekokta sirih hijau dalam sediaan gel serta menguji sifat-sifat sediaan termasuk aktivitas antibakterinya dalam rangka menemukan alternatif pencegahan mastitis pada sapi.

\section{METODOLOGI \\ Bahan penelitian}

Serbuk daun sirih hijau diambil dari Ngupasan, Gondomanan, Yogyakarta; akuades, karbopol, metil paraben, dan gliserin dari CV. General Labora, Yogyakarta; $\mathrm{NaOH}$, media nutrient broth dan nutrient agar dari Merck; bakteri S.aureus ATCC 25923 dan bakteri E.coli ATCC 25922 dari Laboratorium Mikrobiologi, Fakultas Farmasi UGM.

\section{Alat}

Panci dekokta, seperangkat alat uji daya lekat, autoklaf, laminar air flow, neraca analitik (Ohaus), inkubator (Memmert), mikropipet (Socorex), dan viskometer (Brookfield).

\section{Jalannya Penelitian}

Preparasi Bahan Baku

Serbuk daun sirih hijau sebanyak 100 gram diekstraksi menggunakan metode dekokta dalam akuades $500 \mathrm{~mL}$, yaitu dengan akuades pada suhu $90^{\circ} \mathrm{C}$ selama 30 menit. Ekstrak cair (dekokta) yang diperoleh segera digunakan untuk membuat sediaan gel.

\section{Formulasi Gel}

Pembuatan sediaan gel dilakukan sesuai komposisi pada Tabel I. Karbopol dikembangkan dengan sebagian air panas, dan diaduk hingga homogen dalam mortar. Larutan $\mathrm{NaOH}$ ditambahkan ke dalam larutan karbopol dan diaduk hingga membentuk massa yang kental, selanjutnya disebut dengan campuran 1 . Metil paraben dicampurkan dengan gliserin dan DDSH hingga homogen. Campuran ini ditambahkan sedikit demi sedikit ke dalam campuran 1 dan diaduk hingga homogen. 
Sisa akuades ditambahkan ke dalam campuran tersebut hingga mencapai 100\%. Penyimpanan dilakukan pada wadah tertutup rapat, terlindung cahaya pada suhu ruang $\left( \pm 25^{\circ}\right)$. Dalam penelitian ini ingin diketahui formula uji yang paling baik diantara kelima formula dalam hal efektivitas antibakterinya tetapi tetap memenuhi syarat fisik sebagai sediaan gel sebagaimana uji yang dilakukan dalam penelitian ini.

\section{Uji Sifat Fisik Gel \\ Organoleptik}

Uji organoleptis dilakukan pada hasil sediaan gel DDSH yang meliputi pengamatan warna, bau, dan bentuk sediaan gel.

\section{Homogenitas}

Sediaan diambil pada 3 titik sampling yang berbeda dan dioleskan pada kaca transparan. Jika tidak ada butiran kasar maka sediaan uji dinyatakan homogen (Nikam, 2017).

Nilai $\mathrm{pH}$

Uji pH sediaan gel diukur dengan menggunakan stik pH universal dengan cara dicelupkan ke dalam sampel gel. Nilai $\mathrm{pH}$ sediaan yang memenuhi kriteria $\mathrm{pH}$ kulit dan tidak mengiritasi yaitu pH 4,5-6,5 (Okuma dkk., 2015; Nikam, 2017).

\section{Daya Sebar}

Sebanyak 0,5 gram sediaan yang diletakkan pada bagian tengah kaca bulat berskala, kemudian ditutup dengan kaca bulat lain. Pengukuran diameter penyebaran sediaan secara membujur dan melintang, serta dilakukan tiap penambahan beban 50 gram hingga berat total 150 gram. Daya sebar yang memenuhi syarat yaitu 5-7 cm (Yusuf dkk., 2017).

\section{Daya Lekat}

Uji daya lekat dilakukan dengan meletakkan 0,5 gram gel di atas kaca obyek kemudian ditutup dengan kaca obyek lainnya, dan diberi beban beban $1 \mathrm{~kg}$ selama 3 menit. Penentuan daya lekat berupa waktu yang diperlukan sampai kedua kaca obyek terlepas. Syarat daya lekat yaitu lebih dari 1 detik (Yusuf dkk., 2017).

Viskositas

Uji viskositas dilakukan menggunakan viscometer terhadap $100 \mathrm{~mL}$ sediaan gel.
Viskositas gel yang baik sebesar 2000 - 4000 cps (Ardana dkk., 2015).

\section{Uji Aktivitas Antibakteri Gel Terhadap S.aureus dan E.coli \\ Pembuatan suspensi bakteri}

Pembuatan suspensi bakteri dilakukan dengan melakukan inokulasi bakteri $S$. aureus atau E. coli ke dalam $20 \mathrm{~mL}$ media NB, lalu diinkubasi pada suhu $37^{\circ} \mathrm{C}$ pada shaker incubator dengan kecepatan $150 \mathrm{rpm}$ diperoleh nilai $\mathrm{OD}_{600}$ sebesar $0,35-0,4$.

Uji difusi dengan sumuran

Preparasi uji difusi dilakukan dengan mencampur $700 \mu \mathrm{L}$ suspensi bakteri dengan 70 mL NA dalam Erlenmeyer, diaduk hingga homogen, kemudian campuran tersebut dituang sebanyak $20 \mathrm{~mL}$ untuk tiap petri, tunggu hingga memadat. Tiap sumuran dengan diameter $6 \mathrm{~mm}$ diisi dengan $50 \mathrm{mg}$ sediaan. Lakukan inkubasi pada suhu $37^{\circ} \mathrm{C}$ selama semalam. Amati zona hambat yang terbentuk dan ukur dengan jangka sorong. Daya hambat ditunjukkan dengan menghitung selisih antara zona hambat keseluruhan dengan diameter plug (6 mm).

\section{Uji Stabilitas dengan Cycling Test}

Uji stabilitas viskositas dan aktivitas antibakteri terhadap $S$. aureus serta $E$. coli dilakukan dengan metode cycling test selama 6 siklus. Pada tiap siklusnya, sediaan uji disimpan pada suhu $4^{\circ} \mathrm{C}$ selama 24 jam dilanjutkan penyimpanan pada suhu $40^{\circ} \mathrm{C}$ selama 24 jam (Dewi dkk., 2014).

Analisis Data

Analisis data dilakukan terhadap stabilitas viskositas dan aktivitas antibakteri sebelum dan sesudah penyimpanan dengan metode cycling test. Analisis data dilakukan menggunakan perangkat lunak SPSS versi 22 yaitu dengan uji normalitas Kolmogorov-Smirnov dilanjutkan dengan uji T dengan taraf kepercayaan 95\%.

\section{HASIL DAN PEMBAHASAN}

Secara teoritis, peningkatan konsentrasi zat aktif akan meningkatkan aktivitas antibakterinya. Namun, dengan meningkatkan zat aktif belum tentu dapat menghasilkan sifat fisik yang memenuhi syarat. Oleh karena itu, pada penelitian ini dilakukan variasi konsentrasi dekokta daun sirih yang lebar, yaitu mulai dari $10 \%$ hingga $80 \%$, dengan tujuan 
Tabel II. Hasil uji pH, daya sebar, dan daya lekat gel dekokta daun sirih hijau

\begin{tabular}{cccc}
\hline Formula & pH & Daya sebar $\mathbf{( c m )}$ & Daya lekat (detik) \\
\hline F1 & 6,50 & $3,20 \pm 0,17$ & $11,79 \pm 0,96$ \\
F2 & 6,50 & $3,33 \pm 0,08$ & $6,21 \pm 0,53$ \\
F3 & 6,00 & $4,38 \pm 0,15$ & $2,45 \pm 0,14$ \\
F4 & 6,00 & $6,13 \pm 0,49$ & $0,27 \pm 0,06$ \\
F5 & 5,50 & Terlalu menyebar & Tidak dapat melekat \\
\hline
\end{tabular}

Semakin tinggi konsentrasi menghasilkan warna gel yang semakin gelap, seperti tertera pada Gambar 1.

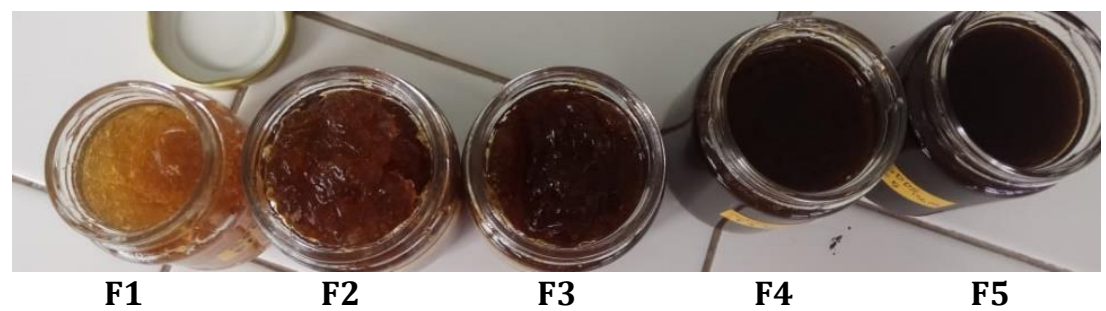

Gambar 1. Penampakan fisik gel dekokta daun sirih hijau kelima formula sebelum penyimpanan dengan metode cycling test.

untuk mengetahui pengaruh konsentrasi tersebut terhadap aktivitas dan sifat fisik gel dengan lebih nyata.

Karbopol merupakan gelling agent yang bersifat asam dan dapat efektif membentuk konsistensi yang kental, bersih tanpa gelembung udara, membentuk gel yang transparan pada $\mathrm{pH}$ netral, sehingga dalam pembuatan gel dengan karbopol diperlukan proses netralisasi agar efektivitas karbopol dalam meningkatkan viskositas dapat tercapai (Nikam, 2017), yang mana dapat dilakukan dengan menambahkan natrium hidroksida yang bersifat basa. Karbopol juga memiliki kelebihan yaitu tidak menimbulkan hipersensitivitas serta melekat baik pada kulit (Tambunan dan Sulaiman, 2018). Penggunaan karbopol sebagai gelling agent yaitu berkisar 0,5-2\%. Karbopol merupakan gelling agent yang paling baik dibanding polimer lain yaitu karboksimetil siloglukan, karboksimetil selulosa natrium, metil selulosa, dan hidroksipropil metilselulosa. Sediaan gel menggunakan polimer karbopol memberikan viskositas yang paling tinggi namun tetap menghasilkan daya sebar yang baik, homogen dan memiliki daya lekat yang baik pada kulit (Bhalekar dkk., 2015).

Zat aktif dan karbopol merupakan komposisi penting dalam pembuatan sediaan gel. Selain komponen tersebut, pengawet dan humektan juga diperlukan dalam komposisi sediaan gel. Pengawet berperan penting dalam mengontrol pertumbuhan mikroba dan jamur dalam proses penyimpanan dan pendistribusian. Metil paraben merupakan salah satu jenis pengawet yang umum digunakan dalam sediaan farmasi yang larut dalam air (Mirsonbol dkk., 2014). Suatu humektan dapat digunakan untuk mempertahankan kelembaban kulit karena dapat menyimpan air di dalam lapisan stratum corneum kulit sehingga kulit menjadi lembab (kelembaban 70\%). Bahan yang dapat digunakan sebagai humektan dan mencegah kehilangan air dalam lapisan stratum corneum yaitu gliserin (Levi dkk., 2011).

\section{Evaluasi sifat fisik formula gel}

Hasil uji organoleptis lima formula gel dekokta daun sirih diperoleh aroma khas daun sirih. Konsentrasi dekokta 10\% memiliki aroma yang lemah, sedangkan sediaan dengan dekokta $27,5 \%, 45 \%, 62,5 \%$ dan $80 \%$ memiliki aroma yang kuat (Tabel II).

Kelima formula gel yang dibuat menghasilkan sediaan yang homogen, dibuktikan dengan tidak ada butiran kasar jika gel dioleskan pada kaca uji. Formula 2, 3, dan 4 menunjukkan konsistensi yang lebih homogen dibandingkan formula 1 dan 5. Pada formula 1 , jumlah akuades dan karbopol yang digunakan jauh lebih banyak, sehingga menghasilkan 


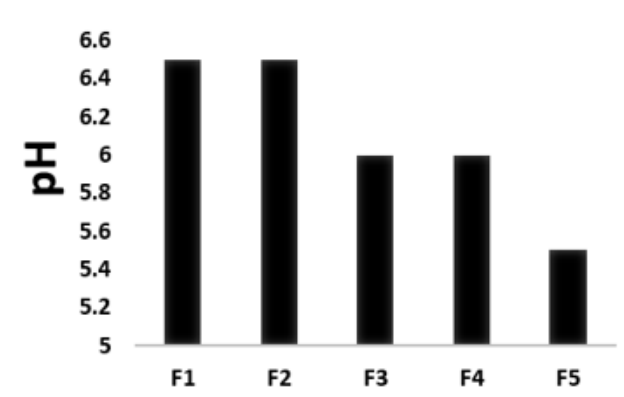

(a)

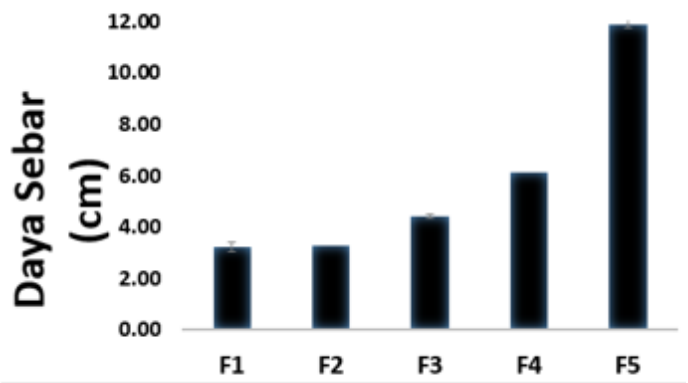

(b)

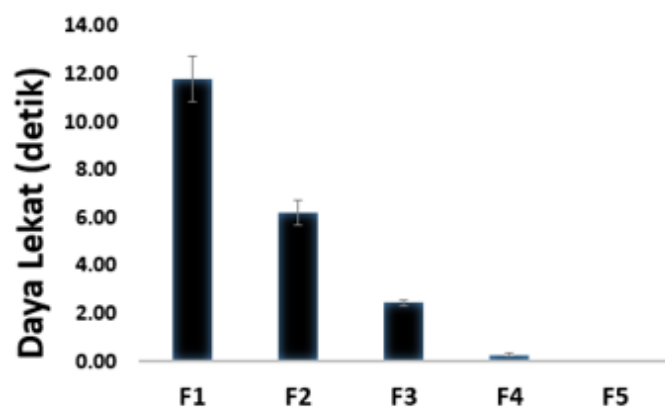

(c)

Gambar 2. Hasil uji sifat fisik gel dekokta daun sirih hijau sebelum penyimpanan dengan metode cycling test berupa uji pH (a), daya sebar (b), dan daya lekat (c).

massa yang sangat kental sehingga dapat meningkatkan kesulitan dalam proses pencampuran.

Hasil penelitian menunjukkan bahwa semakin tinggi konsentrasi dekokta daun sirih maka menghasilkan $\mathrm{pH}$ sediaan yang semakin rendah. Hal ini dikarenakan daun sirih banyak mengandung senyawa fenol seperti kavikol, eugenol, kavibetol, piperitol, timol, serta asamasam organik seperti asam stearat, asam prokatekuat, dan asam galat (Pradhan dkk., 2013). Nilai pH kelima formula sediaan (Gambar 2) memenuhi kriteria $\mathrm{pH}$ sediaan yang tidak mengiritasi kulit yaitu pH 4,5-6,5 (Okuma dkk., 2015; Nikam, 2017). Hasil tersebut menunjukkan bawah penambahan natrium hidroksida yang digunakan sudah cukup untuk menyeimbangkan $\mathrm{pH}$ sediaan sehingga sesuai dengan $\mathrm{pH}$ kulit. Nilai $\mathrm{pH}$ yang lebih rendah dapat menyebabkan iritasi pada kulit sapi dan berdampak negatif bagi bayi sapi saat menyusui. Nilai pH yang terlalu tinggi dapat menyebabkan kekeringan pada kulit dan jika terus berlanjut dapat menyebabkan iritasi kulit, seperti gatal, ruam, memerah dan berisik (Bhalekar dkk., 2015).

Secara teoritis, daya lekat yang memenuhi syarat sediaan kosmetik yaitu lebih dari 1 detik. Hasil penelitian menunjukkan bahwa formula dengan konsentrasi karbopol $1,25-2 \%$ yang memenuhi syarat uji daya lekat, yaitu formula 1,2 , dan 3 , yaitu sebesar 2,45 $\pm 0,14$ detik, 6,21 $\pm 0,53$ detik, dan $11,79 \pm 0,96$ detik (Gambar 2). Jumlah karbopol sebagai gelling agent yang semakin berkurang akan mengubah konsistensi sediaan gel menjadi lebih cair sehingga daya lekatnya berkurang. Uji daya lekat ini menunjukkan kemampuan sediaan dalam melekat pada tempat aplikasinya. Semakin lama sediaan dapat melekat maka semakin lama zat aktif dapat kontak dengan tempat aplikasi sehingga diharapkan efek antibakterinya dapat lebih optimal (Ismarani dkk, 2014; Yusuf dkk., 2017)

Hasil uji daya sebar menunjukkan bahwa semakin tinggi konsentrasi dekokta daun sirih dan semakin rendah konsentrasi karbopol maka semakin rendah daya sebarnya (Gambar 2). Formula dengan dekokta daun sirih $80 \%$ dan karbopol 0,5\% menghasilkan sediaan gel yang sangat encer dan saat diuji terlalu menyebar pada seluruh permukaan alat uji sehingga tidak dapat diukur daya sebarnya. Uji ini menunjukkan kemampuan sediaan dalam menyebar pada permukaan kulit sehingga mempermudah penggunaan sediaan saat 
Tabel III. Hasil uji viskositas gel dekokta daun sirih hijau

\begin{tabular}{ccc}
\hline \multirow{2}{*}{ Formula } & \multicolumn{2}{c}{ Viskositas (cps) } \\
\cline { 2 - 3 } & Sebelum cycling test & Setelah cycling test \\
F1 & $54.587 \pm 839$ & $29.280 \pm 480^{*}$ \\
F2 & $45.400 \pm 3.683$ & $26.733 \pm 61^{*}$ \\
F3 & $30.773 \pm 1.548$ & $16.027 \pm 441^{*}$ \\
F4 & $7.227 \pm 1.092$ & $4.040 \pm 69^{*}$ \\
F5 & $278 \pm 7$ & $1.703 \pm 55^{*}$ \\
\hline
\end{tabular}

Tanda* menunjukkan adanya perbedaan yang signifikan antara sebelum dan sesudah cycling test

diaplikasikan. Sediaan yang sulit menyebar atau terlalu menyebar akan mengurangi tingkat kenyamanan penggunaan dan efektivitas penggunaan sediaan, sedangkan sediaan yang terlalu encer akan menyebabkan daya lekatnya berkurang sehingga waktu kontak zat aktif dengan tempat aplikasi juga berkurang. Hanya formula 4 dengan konsentrasi dekokta daun sirih 62,5\% dan karbopol 0,875\% (Tabel II) yang menghasilkan daya sebar yang baik, yaitu sebesar 6,13 $\pm 0,49 \mathrm{~cm}$ (Bhalekar dkk., 2015; Nikam, 2017; Yusuf dkk., 2017).

\section{Evaluasi viskositas formula gel}

Viskositas mempengaruhi daya sebar sediaan. Semakin tinggi viskositas maka daya sebar semakin rendah, dan sebaliknya (Bhalekar dkk., 2015). Hasil penelitian menunjukkan bahwa formula 4 yang paling mendekati syarat viskositas yang baik menurut Ardana dkk. (2015), yaitu dengan konsenrasi karbopol sebesar 0,875\% (Tabel III). Formula dengan konsentrasi karbopol 1,25-2\% menghasilkan gel dengan viskositas yang tinggi (kental) yaitu lebih dari 30.000 cps sehingga menghasilkan daya sebar yang rendah, di bawah $5 \mathrm{~cm}$, sedangkan formula 5 dengan konsentrasi karbopol 0,5\% menghasilkan gel dengan viskositas sangat encer sehingga sulit diamati daya sebarnya (Tabel II dan III). Hasil pada Tabel III menunjukkan bahwa semakin tinggi konsentrasi dekokta daun sirih maka viskositas gel yang dihasilkan menjadi lebih rendah. Hal ini disebabkan dekokta daun sirih hijau mengandung senyawa yang memberikan kondisi asam pada sediaan. Kondisi asam dapat menurunkan efektivitas dari karbopol sehingga sediaan yang dihasilkan akan menjadi lebih encer (Mardikasari dkk., 2017; Nikam, 2017; Pradhan dkk., 2013).

Dari Tabel III dapat dilihat bahwa setelah sediaan disimpan dalam suhu rendah maka akan terjadi pelepasan air dari sediaan. Namun jika gelling agent dapat bekerja kembali di bawah tekanan yang diinduksi oleh es sebelum koalesens terjadi maka sistem gel tersebut akan stabil atau tidak terjadi pemisahan (Dewi dkk., 2014). Hasil uji normalitas KolmogorovSmirnov dengan perangkat lunak SPSS menunjukkan bahwa data telah terdistribusi merata, sehingga dapat dilanjutkan uji T. Hasil uji statistik ini menunjukkan bahwa nilai viskositas sebelum dan sesudah penyimpanan seluruh formula tidak stabil, yaitu mengalami perubahan secara signifikan $(\mathrm{p}<0,05)$.

Formula 1-4 mengalami penurunan viskositas yang signifikan, hingga hampir 50\%. Namun, hanya formula 4 yang masih masuk dalam rentang viskositas gel yang baik menurut Ardana dkk. (2015). Hal ini membuktikan sediaan gel yang dihasilkan tidak tahan terhadap penyimpanan pada perubahan suhu ekstrim sehingga suhu penyimpanan sediaan perlu diperhatikan. Viskositas dipengaruhi oleh suhu, yang mana suhu yang meningkat akan mengurangi gaya antar atom dengan cara memperbesar jarak antara atom sehingga viskositas sediaan menjadi menurun (Dewi dkk., 2014). Fomula 5 setelah penyimpanan dengan metode cycling test menjadi lebih kental hingga 5 kali lipat. Pada proses penyimpanan tersebut memungkinkan kandungan air dalam gel berkurang sehingga menyebabkan gel lebih kental. Kandungan air dengan dekokta konsentrasi tinggi pada formula 5 lebih banyak dibanding dengan formula yang lain, sehingga memungkinkan viskositas gel berubah menjadi lebih tinggi (Mardikasari dkk., 2017).

Karbopol efektif sebagai gelling agent pada $\mathrm{pH}$ netral, yaitu suatu kondisi dimana tidak ada muatan ion dalam larutan. Pada $\mathrm{pH}$ netral, konsentrasi ikatan polimer yang terbentuk dapat meningkat. Selain itu, afinitas pelarut terhadap polimer maka akan meningkatkan 


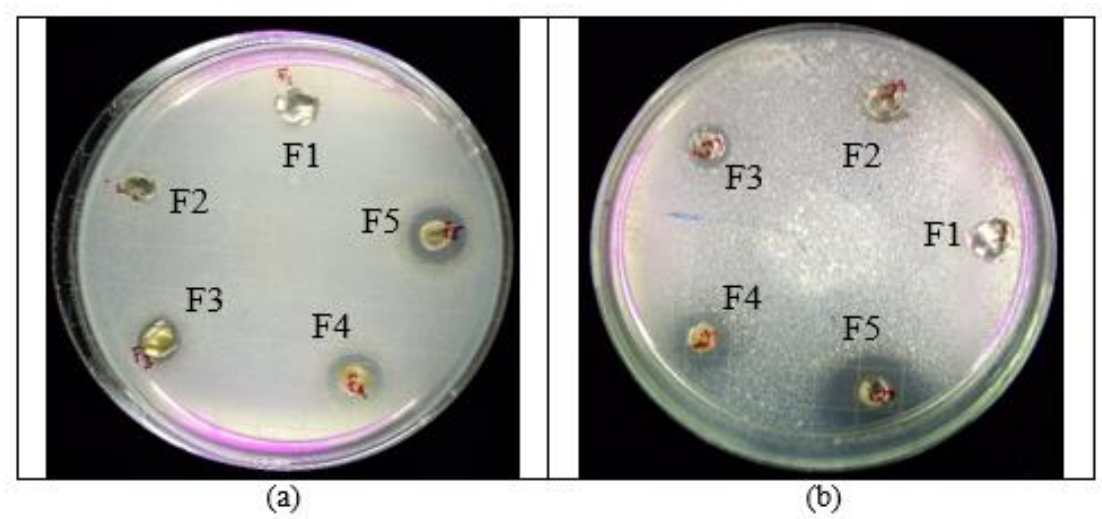

Gambar 3. Penampakan uji aktivitas antibakteri gel dekokta daun sirih hijau terhadap bakteri S.aureus (a) dan E.coli (b) sebelum penyimpanan dengan metode cycling test.

pembentukan struktur jaringan pembentuk gel. Peningkatan struktur jaringan dan kemampuan mengembang dari polimer tersebut dapat meningkatkan viskositas sediaan. Afinitas karbopol terhadap etanol lebih tinggi dibanding air sebagai pelarut (Nikam, 2017). Penggunaan air sebagai pelarut dalam penelitian ini dapat menjadi penyebab penurunan efektivitas karbopol dalam meningkatkan viskositas sediaan.

\section{Evaluasi aktivitas antibakteri}

Uji aktivitas antibakteri dilakukan menggunakan metode difusi padat dengan sumuran (Gambar 3). Metode ini dipilih karena mudah dalam melakukan sampling, aplikatif, serta mudah dalam pengamatan dan analisisnya.

Bakteri S. aureus yang digunakan merupakan bakteri Gram positif yang dapat menyerang puting sapi, sedangkan bakteri $E$. coli merupakan bakteri Gram negatif yang ikut andil dalam proses terjadinya penyakit mastitis pada sapi. Pemilihan kedua bakteri yang berasal dari jenis Gram yang berbeda ini diharapkan dapat mewakili bakteri-bakteri yang dapat menyebabkan mastitis pada sapi (Verbree dkk., 2017).

Hasil uji aktivitas antibakteri pada penelitian ini menunjukkan bahwa pada konsentrasi dekokta daun sirih $10 \%$ dan 27,5\% pada sediaan gel belum mampu membunuh bakteri uji. Hal ini dapat dilihat dari tidak adanya zona jernih di sekeliling sumuran yang berisi gel formula 1 dan 2 (Tabel IV). Faktor yang dapat menghambat aktivitas tersebut yaitu adanya zat aktif yang terjebak dalam sediaan gel sehingga akan mengalami kesulitan untuk berdifusi pasif keluar sediaan menuju lokasi target, yaitu media pertumbuhan bakteri.

Konsentrasi terendah dekokta daun sirih dalam sediaan gel yang masih mampu membunuh bakteri uji yaitu sebesar 45\%, dengan konsentrasi karbopol 1,25\%. Perbandingan konsentrasi zat aktif dengan gelling agent sudah cukup untuk memberikan peluang bagi zat aktif berdifusi pasif keluar sediaan menuju media kultur dan membunuh bakteri yang ada pada media tersebut. Hasil uji aktivitas antibakteri juga menunjukkan bahwa semakin tinggi konsentrasi dekokta daun sirih maka akan semakin tinggi aktivitas antibakterinya karena semakin banyak pula kandungan zat aktif yang dapat membunuh bakteri uji.

Senyawa flavonoid dapat menurunkan permeabilitas dinding sel bakteri $S$. aureus dan E. coli. Senyawa ini memiliki kemampuan melakukan denaturasi protein sel bakteri dan merusak membran sel. Sementara itu, saponin mampu menurunkan tegangan permukaan dinding sel bakteri dan merusak permeabilitas membran. Adanya gangguan tegangan permukaan dinding sel menyebabkan zat antibakteri dengan mudah masuk ke dalam sel sehingga sel dapat mengalami kematian. Tanin merupakan antibakteri dengan cara menghambat pembentukan dinding sel sehingga menyebabkan sel bakteri menjadi lisis. Adanya ikatan antara tanin dan dinding sel bakteri menyebabkan kemampuan menempel bakteri menjadi inaktif dan menghambat pertumbuhannya (Marsono dkk., 2017).

Hasil uji stabilitas aktivitas terhadap bakteri $S$. aureus (Tabel IV) dengan metode cycling test untuk formula 3 tidak mengalami 
Tabel IV. Hasil uji aktivitas gel dekokta daun sirih hijau terhadap bakteri S.aureus dan E.coli.

\begin{tabular}{ccccc}
\hline Formula & Terhadap Bakteri S.aureus (mm) & \multicolumn{2}{c}{ Terhadap Bakteri E.coli (mm) } \\
\cline { 2 - 5 } & $\begin{array}{c}\text { Sebelum } \\
\text { cycling test }\end{array}$ & $\begin{array}{c}\text { Sesudah } \\
\text { cycling test }\end{array}$ & $\begin{array}{c}\text { Sebelum } \\
\text { cycling test }\end{array}$ & $\begin{array}{c}\text { Sesudah } \\
\text { cycling test }\end{array}$ \\
\hline F1 & 0 & 0 & 0 & 0 \\
F2 & 0 & 0 & 0 & 0 \\
F3 & $1,77 \pm 0,8$ & $1,11 \pm 0,57$ & $3,13 \pm 1,58$ & $1,63 \pm 0,29$ \\
F4 & $4,82 \pm 0,7$ & $0,71 \pm 0,13^{*}$ & $3,85 \pm 1,52$ & $2,62 \pm 0,23$ \\
F5 & $5,73 \pm 0,3$ & $0,70 \pm 0,55^{*}$ & $7,00 \pm 2,26$ & $3,80 \pm 0,20^{*}$ \\
\hline
\end{tabular}

Tanda * menunjukkan adanya perbedaan yang signifikan antara sebelum dan sesudah cycling test Hasil uji merupakan diameter zona hambat dikurangi dengan diameter plug $(6 \mathrm{~mm})$.

penurunan aktivitas yang signifikan $(\mathrm{P}<0,05)$, sedangkan untuk formula 4 dan formula 5 mengalami penurunan aktivitas secara signifikan $(P>0,05)$. Hasil uji stabilitas aktivitas terhadap bakteri E. coli dengan metode cycling test untuk formula 3 dan 4 tidak mengalami penurunan aktivitas yang signifikan $(\mathrm{P}<0,05)$, sedangkan untuk formula 5 mengalami penurunan aktivitas yang signifikan $(P>0,05)$. Hal ini mungkin terjadi karena senyawa aktif dari daun sirih hijau mengalami oksidasi karena pemanasan. Senyawa fenolik dalam daun sirih hijau seperti eugenol, piperitol, $\alpha$-terpineol, $\beta$ sitosterol, dan kavikol mudah mengalami oksidasi (Pradhan dkk., 2013). Secara garis besar, aktivitas gel dekokta daun sirih hijau terhadap bakteri E. coli (Gram negatif) lebih tinggi dibanding aktivitasnya terhadap bakteri S. aureus (Gram positif).

\section{KESIMPULAN}

Semakin besar konsentrasi dekokta, sediaan akan semakin encer, semakin asam dan semakin besar daya antibakterinya, sedangkan semakin besar konsentrasi karbopol, viskositas gel akan semakin besar. Dari hasil kombinasi data setiap formula, yaitu dengan memperhatikan daya antibakteri dan sifat fisik gel dalam setiap formula, maka formula 4 merupakan formula yang paling optimal dalam penelitian ini.

\section{UCAPAN TERIMA KASIH}

Ucapan terima kasih kepada Yayasan Bhakti Setya Indonesia selaku pemberi dana penelitian ini, serta staf Laboratorium Mikrobiologi dan Laboratorium Teknologi Farmasi, Fakultas Farmasi, Universitas Gadjah Mada, Yogyakarta, yang telah membantu penelitian ini.

\section{DAFTAR PUSTAKA}

Agustinus, L., 2015, Efektivitas Antibakteri Eugenol Minyak Daun Cengkeh (Clove Leaf Oil) terhadap Bakteri Penyebab Mastitis Subklinis Sapi Perah, Disertasi, Universitas Brawijaya, Malang.

Ardana, M., Aeyni, V., dan Ibrahim, A., 2015, Formulasi dan Optimasi Basis Gel HPMC (Hidroxy Propyl Methyl Cellulose) dengan Berbagai Variasi Konsentrasi, J. Trop. Pharm. Chem., 3 (2):101-108.

Bhalekar, M.R., Madgulkar, A.R., dan Kadam, G.J., 2015, Evaluation of Gelling Agent for Clindamycin Phosphate Gel, World J. Pharm. Pharmaceutic. Sci., 4 (7):20222033.

Cazoto, L.L., Martins, D., Ribeiro, M.G., Durán, N., dan Nakazato, G., 2011, Antibacterial Activity of Violacein Against Staphylococcus aureus isolated from Bovine Mastitis, J. Antibiot., 64:395-397.

DepKes RI, 2012, Peraturan Menteri Kesehatan Republik Indonesia Nomor 007 Tahun 2012 Tentang Registrasi Obat Tradisional, DepKes RI, Jakarta.

Dewi, R., Anwar, E., dan Yunita, K.S., 2014, Uji Stabilitas Fisik Formula Krim yang Mengandung Ekstrak Kacang Kedelai (Glycine max), Pharm. Sci. Res., 1 (3):194208.

Ismarani, D., Pratiwi, L., dan Kusharyanti, I., 2014, Formulasi Gel Pacar Air (Impatiens balsamina Linn.) terhadap Propionibacterium acnes dan Staphylococcus epidermidis, Pharm. Sci. Res., 1 (1):30-45.

Levi, K., Kwan, A., dan Rhines, A.S., 2011, Effect of Glycerin on Drying Stresses in Human Stratum Corneum, J. Dermatol. Sci., 61 (2):129-131. 
Mardikasari, S.A., Mallarangeng, A.N.T.A., Zubaydah, W.O.S., dan Juswita, E., 2017, Formulasi dan Uji Stabilitas Lotion dari Ekstrak Etanol Daun Jambu Biji (Psidium guajava L.) Sebagai Antioksidan, Jurnal Farmasi, Sains, dan Kesehatan, 3 (2):2832.

Marsono, O.S., Susilorini, T.E., dan Surjowardojo, P., 2017, Pengaruh Lama Penyimpanan Dekok Daun Sirih Hijau (Piper Betle L.) terhadap Aktivitas Daya Hambat Bakteri Streptococcus agalactiae Penyebab Matitis pada Sapi Perah, Jurnal Ilmu dan Teknologi Hasil Ternak, 12 (1):47-60.

Mirsonbol, A.Z., Issazadeh, K., Pahlaviani, M.R.M.K., dan Momeni, N., 2014, Antimicrobial Efficacy of The Methylparaben and Benzoate Sodium Against Selected Standard Microorganisms, Clinical and Environmental Isolates In Vitro, Indian Journal of Fundamental and Applied Life Sciences, 4 (4):363-367.

Nikam, S., 2017, Anti-acne Gel of Isotretinoin: Formulation and Evaluation, Asian J. Pharm. Clin. Res., 10 (11):257-266.

Nurhayati, I.S., dan Martindah, E., 2015, Pengendalian Mastitis Subklinis melalui Pemberian Antibiotik Saat Periode Kering pada Sapi Perah, WARTAZOA, 25 (2):65-74.

Okuma, C.H., Andrade, T.A.M., Caetano, G.F., Finci, L.I., Maciel, N.R., Topan, J.F., Cefali, L.C., Polizello, A.C.M., Carlo, T., Rogerio, A.P., Sapadaro, A.C.C., Isaac, V.L.B., Frade, M.A.C., dan Rocha-Filho, P.A., 2015, Development of lamellar gel phase emulsion containing marigold oil (Calendula officinalis) as a potential modern wound dressing, Eur. J. Pharm. Sci., 71:62-72.

Pradhan, D., Suri, Dr.K.A., Pradhan, Dr.D.K., dan Biswasroy, P., 2013, Golden Heart of the Nature: Piper betle L., J. Pharmacogn. Phytochem., 1 (6):147-167.

Schmelcher, M. Powell, A.N., Becker, S.C., Camp, M.J., dan Donovan, D.M., 2012, Chimeric Phage Lysins Act Synergistically with Lysostaphin To Kill Mastitis-Causing Staphylococcus aureus in Murine Mammary Glands, Appl. Environ. Microbiol., 78 (7):2297-2305.

Surjowardojo, P. 2011. Tingkat Kejadian Mastitis Dengan Whiteside Test Dan Produksi Susu Sapi Perah Friesien Holstein. J. Ternak Tropika. 12 (1): 46-55.

Tambunan, S., dan Sulaiman, T.N.S., 2018, Formulasi Gel Minyak Atsiri Sereh dengan Basis HPMC dan Karbopol, Majalah Farmaseutik, 14 (2):87-95.

Verbree, C.T., Dätwyler, S.M., Meile, S., Eichenseher, F., Donovan, D.M., Loessner, M.J., dan Schmelcher, 2018, Corrected and Republished from: Identification of Peptidoglycan Hydrolase Constructs with Synergistic Staphylolytic Activity in Cow's Milk, Appl. Environ. Microbiol., 84 (1):1-15.

Yusuf, A.L., Nurawaliah, E., dan Harun, N., 2017, Uji Efektivitas Gel Ekstrak Etanol Daun Kelor (Moringa oleifera L.) sebagai Antijamur Malassezia furfur, Kartika: Jurnal Ilmiah Farmasi, 5 (2):62-67. 